\title{
Bacteriocin-mediated inhibition of some common pathogens by wild and mutant Lactobacillus species and in vitro amplification of bacteriocin encoding genes
}

\author{
Arooj Ahsan ${ }^{1}$, Bushra Mazhar ${ }^{1}$, Muhammad Kamran Khan ${ }^{1}$, Madiha Mustafa ${ }^{2}$, \\ Muhammad Hammad ${ }^{3}$, Nazish Mazhar $\mathrm{Ali}^{1 *}$ \\ ${ }^{1}$ Department of Zoology, GCU Lahore, Pakistan \\ ${ }^{2}$ Qarshi University Lahore, Pakistan \\ ${ }^{3}$ University of Education, Lahore, Pakistan \\ *Corresponding author: E-mail: nazipak@hotmail.com.
}

Received: July 08, 2021; Revised: October 14, 2021; Available online: November 14, 2021

\begin{abstract}
Lactobacilli are the most common probiotics used in food and other industries because of their capability of producing bacteriocins. Bacteriocins are compounds that are used to kill pathogenic microorganisms. As most bacteria have become resistant to synthetic antibacterial tools, the importance of using probiotics as antibacterial agents has increased. This work was done to check the bacteriocin effect on some common pathogens and the influence of mutation on the bacteriocin activity of Lactobacilli was also investigated. Four strains were isolated, identified from meat and pickles samples via culturing methods, staining, biochemical tests, and ribotyping. Preliminary tests, including Gram staining and catalase test, were done for the confirmation of Lactobacillus species. All strains were gram-positive and catalase-negative. Antibacterial activity was checked against Pseudomonas aeruginosa, Staphylococcus aureus, Bacillus thuringiensis, Escherichia coli, and Salmonella enteritis via agar well diffusion method. The mutations were done using ethidium bromide and the influence of wild and mutants were also checked. Interestingly, mutants developed more virulence than wild ones. It was also observed that they all were sensitive to pepsin. Protein estimation was done via Bradford method. Ribotyping of GCU-W-PS1 revealed $99 \%$ homology with Lactobacillus plantarum and GCU-W-MS1 to Lactobacillus curvatus (99\% homology). Curvacin A, sakacin $P$, and plantaricin A genes were also amplified using specific primers. Gene sequence showed the presence of curvacin A gene in GCU-W-MS1. It was concluded that lactic acid bacteria could be used as antibacterial tools against common pathogens.
\end{abstract}

(02021 by the authors. This article is an open-access article distributed under the terms and conditions of the Creative Commons Attribution license (http://creativecommons.org/licenses/by/4.0/).

\section{Keywords}

Bacteriocin; antibacterial activity; Lactobacilli; bacteriocin encoding genes.

\section{Introduction}

Bacteriocins are compounds produced by different bacterial strains and are ribosomally synthesized antimicrobial proteins. Their function is to inhibit the growth of similar or closely related bacterial strains [1]. Many lactic acid bacteria are found infrequently fermented or non-fermented foods, producing a high 
variety of bacteriocins. Some of the bacteriocins even have the potential to preserve food, which helps foods preserve nature and not only preserve but also restore the nutritional properties of food. In industries, we preserve food by using chemicals, though it is successful, the quality of food becomes doubtful. So for this purpose, the alternative technique that could be used is applied bacteriocin and act as bio preservatives [2]. Nisin is the only bacteriocin that is broadly used for food preservation now a day. It is the most extensively implemented bacteriocin. It is vigorous against highly pathogenic and food spoilage microorganisms, including S. aureus and Listeria monocytogenes [3]. But scientists are doing work on many bacteriocins to characterize them biochemically, chemically, and genetically so that we will be able to understand their basic mode of action. As a result of which we will revolutionize the food industry [4]. By inducing mutation in Lactobacillus we can improve the potency at elevated temperatures, also broadening the antibacterial spectrum [5]. Mutation is a method of changing organisms genetically. Either this mutation will be beneficial for us or may make the organism more vulnerable for mankind. Mutagenesis can be done with ethidium bromide [6] and ultraviolet (UV) light [7]. Ethidium bromide is a frame-shift mutagen genotoxic and teratogen which usually become the cause of changes like frame-shift mutation, chromosomal recombination, arrested cell division and developmental problem. However, it has been noted that such types of mutations have positive effects and usually increase the efficiency of mutants in contrast to wild ones. Mutagenic activities can be optimized by knowing the type of mutagens and dosage. Mutagens specificity effects may also help in the optimization. Mutagenesis can be improved or directed to achieve the maximum frequency of enviable mutant products [8]. The objectives of the current work were to isolate, identify, and characterize the lactobacillus species from meat and pickle samples, to check the virulent effect of wild and mutant species of Lactobacillus against common pathogenic bacteria, and to detect bacteriocin encoding genes in different wild and mutant species of Lactobacilli species.

\section{Importance of work}

Bacteria develop resistance against many antibacterial agents currently used, so it is a dire need to develop new strategies to control these pathogenic bacteria. Lactobacilli are used as probiotics and are now extensively studied for their antibacterial activity against common pathogens. These bacteria produce bacteriocin, which has an impact on pathogens. We studied and detected the bacteriocin encoding genes in our native lactobacilli (wild and mutant), did ribotyping, and obtained their accession number from NCBI. This is original research work and our study with native bacterial isolates.

\section{Materials and methods}

\section{Sample collection}

Poultry meat samples and a variety of pickles samples (homemade and companies made) were collected in sterilized bags from different shops of Sant Nagar and Krishan Nagar, Lahore, Pakistan.

\section{Preparation of culture media}

For the isolation of Lactobacillus species De Man, Rogosa and Sharpe (MRS) broth (Sigma) (1.5 g of peptone, $1.5 \mathrm{~g}$ of beef extract, $0.75 \mathrm{~g}$ of yeast extract, $3 \mathrm{~g}$ of glucose, $0.15 \mathrm{~g}$ of Tween-80, $0.3 \mathrm{~g}$ of ammonium citrate, $0.75 \mathrm{~g}$ of sodium acetate, $0.03 \mathrm{~g}$ of magnesium sulfate, $0.0075 \mathrm{~g}$ of manganese sulfate and $0.3 \mathrm{~g}$ of dipotassium hydrogen and $150 \mathrm{ml}$ of distilled water) and MRS agar medium (Sigma)(1.5 g of peptone, $0.75 \mathrm{~g}$ of yeast extract, $1.5 \mathrm{~g}$ of beef extract, $3 \mathrm{~g}$ of glucose, $0.15 \mathrm{~g}$ of Tween-80, $0.75 \mathrm{~g}$ of sodium acetate, $0.3 \mathrm{~g}$ of ammonium citrate, $0.03 \mathrm{~g}$ of magnesium sulfate, $0.0075 \mathrm{~g}$ of manganese sulfate, $0.3 \mathrm{~g}$ of dipotassium hydrogen phosphate, $2.25 \mathrm{~g}$ of agar, and $150 \mathrm{ml}$ of distilled water) were prepared with neutral $\mathrm{pH}$. 


\section{Isolation of bacteria via aseptic techniques}

One gram of each sample was taken and mixed with $9 \mathrm{ml}$ of buffered peptone water in the flask. The content was homogenized. The samples were serially diluted and two methods, i.e., spreading and streaking, were used to isolate bacteria on prepared MRS agar medium.

\section{Morphological and biochemical characterization}

Pure cultures were characterized by cell morphology via Gram staining and biochemical characterization via Catalase reaction. Catalase-negative isolates were further analyzed for bacteriocin production.

\section{Agar-well diffusion assay}

The antagonism of bacteriocin-producing strains against responsive strains (gram-positive and gramnegative bacteria) is usually determined using the agar well diffusion method [9]. Potential bacteriocin producers were grown in MRS broth at $37{ }^{\circ} \mathrm{C}$ for $24 \mathrm{~h}$. The size of disposable Petri plates was $60 \mathrm{~mm} \times 15$ $\mathrm{mm}$. Responsive strains were streaked on the agar plates, dried for a few minutes, five wells of $8 \mathrm{~mm}$ were made, and poured with $50 \mu \mathrm{l}$ of an overnight culture of isolated strains. The agar plates were incubated for $30 \mathrm{~min}$ at $4^{\circ} \mathrm{C}$ to allow the diffusion of bacteriocin and incubated overnight at $37^{\circ} \mathrm{C}$. Zones of inhibitions were checked after $24 \mathrm{~h}$ of incubation. The diameter of inhibited zones was measured [10].

\section{Induction of mutagenesis}

Mutagenesis with ethidium bromide was done [11]. Strains of Lactobacilli (i.e., GCU-W-PS1, GCU-W-PS2, GCU-W-MS1, and GCU-W-MS2) were grown up to the late logarithmic phase of growth in trypticase soy broth (TSB). The cells were yielded and washed with $0.9 \% \mathrm{NaCl}$ solution twice and ethidium bromide with a concentration of $0.5,1.0,1.5 \mathrm{~g} / \mathrm{l}$ were added to $2 \mathrm{ml}$ of each cell suspension. The mixture was aerated on a shaking incubator at $30^{\circ} \mathrm{C}$ and $42^{\circ} \mathrm{C}$, respectively. The treated cells were incubated in $10 \mathrm{ml}$ TSB washed twice and re-suspended in $0.9 \% \mathrm{NaCl}$ solution and after serial dilution, it was spread on MRS agar plates and incubated at $30^{\circ} \mathrm{C}$ and $42^{\circ} \mathrm{C}$ for $48 \mathrm{~h}$. Then isolation of mutant was done.

\section{Production of bacteriocins}

$10 \mathrm{ml}$ of MRS broth was prepared in falcon tubes for each isolate and $\mathrm{pH}$ was adjusted to 6.0 to 7.0. Falcon's tubes were autoclaved at $121{ }^{\circ} \mathrm{C}$ and $15 \mathrm{lbs}$. Then $100 \mu \mathrm{l}$ of a freshly prepared broth culture of lactic acid bacteria was inoculated with a micropipette and incubated for 24 hours at $37{ }^{\circ} \mathrm{C}$. After incubation, falcon tubes were placed in a centrifuge (BioRad) for 30 minutes at $8000 \mathrm{rpm}$ at $4{ }^{\circ} \mathrm{C}$. With the help of filter paper, the supernatant was filtered. This filtered supernatant was crude extract.

\section{Protein estimation by Bradford method}

Bradford method [12] was used to determine protein concentrations using a spectrophotometer (BioRad). Bovine serum albumin (BSA) was taken as standard. BSA's stock solution may be prepared if we dissolve $1 \mathrm{mg}$ of $B S A$ in $1 \mathrm{ml}$ of distilled water. Different concentration of bovine serum albumin was prepared for the preparation of the standard curve of BSA. $100 \mu \mathrm{l}$ of each dilution of BSA was taken in test tubes and labeled according to concentration. $100 \mu \mathrm{l}$ of distilled water was taken in the test tube as blank. Then $5 \mathrm{ml}$ of Bradford reagent was added to each test tube mixed and placed at room temperature for 15 minutes. After a few minutes, the sample color changed to blue then the absorbance of the tubes was noted at $595 \mathrm{~nm}$. Graph for the standard curve was plotted, taking concentration along the $\mathrm{x}$-axis and absorbance along the $y$-axis.

\section{Determination of protein concentration}


For preparing the Bradford reagent, we dissolved $100 \mathrm{mg}$ Coomassie Brilliant Blue G-250 in $50 \mathrm{ml} 95 \%$ ethanol; added $100 \mathrm{ml} 85 \%(\mathrm{w} / \mathrm{v})$ with phosphoric acid. Then diluted it to 1 liter. When the dye had completely dissolved, it was filtered through Whatman \#1 paper just before use and stored at $4{ }^{\circ} \mathrm{C}$. To determine the protein concentration of samples, test tubes were labeled according to the sample name and $100 \mu \mathrm{l}$ of protein sample in the form of CFS was taken while the control tube contained only a growth medium (MRS broth). $5 \mathrm{ml}$ of Bradford reagent was added and mixed in each test tube and then incubated at room temperature until it turned blue. The absorbance of the tubes was taken at $595 \mathrm{~nm}$ by spectrophotometer. The absorbance was compared with standard.

\section{Characterization of bacteriocin}

To confirm the proteinaceous nature of bacteriocin, its sensitivity against proteolytic enzymes was tested. Proteolytic enzyme with final concentration of $2 \mathrm{mg} / \mathrm{ml}$ was treated with crude bacteriocin in $0.01 \mathrm{M}$ phosphate buffer at $\mathrm{pH} 7.0,0.15 \mathrm{ml}(150 \mu \mathrm{l})$, phosphate buffer $(0.5 \mathrm{M}, \mathrm{pH} 7.0), 0.15 \mathrm{ml}(150 \mu \mathrm{l})$ of bacteriocin and $0.15 \mathrm{ml}(150 \mu \mathrm{l})$ of pepsin $(0.25 \mathrm{mg} / \mathrm{ml})$ were taken in a test tube. A control was run by taking only $0.15 \mathrm{ml}(150 \mu \mathrm{l})$ of bacteriocin and $0.15 \mathrm{ml}(150 \mu \mathrm{l})$ of distilled water. These samples were kept in an incubator for 2 hours at $37{ }^{\circ} \mathrm{C}$ and then boiled at $100{ }^{\circ} \mathrm{C}$ for 3 to 5 minutes. No zone of inhibition indicates a positive result.

\section{Molecular characterization}

Lactobacillus cells from $24 \mathrm{~h}$ MRS broth cultures were centrifuged at $6000 \mathrm{rpm}$ for $5 \mathrm{~min}$ to pellet out cells for DNA isolation using phenol: chloroform extraction method. Selected bacteriocin-producing strains were finally identified along the partial length of the 16S rRNA gene sequence. Amplification with 16S rRNA gene is used to identify the microbes to specie level. $50 \mu \mathrm{l}$ reaction mixtures were used for PCR amplification using a thermocycler (BioRad1000). The polymerase chain reaction was performed for 35 reaction cycles in a thermocycler. All amplification reactions were performed in a PCR cycling system using the conditions given below: the first cycle was led by initial denaturation at $94{ }^{\circ} \mathrm{C}$ for $5 \mathrm{~min}$, followed by 35 cycles, denaturation at $94{ }^{\circ} \mathrm{C}$ for $0.50 \mathrm{sec}$, annealing gradient ranging from $49.3^{\circ} \mathrm{C}$ to $60.2{ }^{\circ} \mathrm{C}$ for $0.30 \mathrm{sec}$ and polymerization at $72{ }^{\circ} \mathrm{C}$ for $50 \mathrm{sec}$. The reactions were terminated with $10 \mathrm{~min}$ of elongation at $72{ }^{\circ} \mathrm{C}$ and then chilled to $4^{\circ} \mathrm{C}$.

\section{Sequencing and sequence analysis}

PCR product was run on $1 \%$ agarose gel. Bands in the gel were observed in UV (BioRad). The products of PCR were sent to $1^{\text {st }}$ Base Laboratory, Malaysia, for sequencing. The sequences acquired were sent to the National Centre for Biotechnology Information (NCBI) to analyze the nucleotide-nucleotide BLAST data.

\section{Characterization of the bacteriocin structural gene}

Various structurally different bacteriocins have been described to date. We performed PCR amplification experiments to determine whether the selected strains carry structural genes of known species that were the same as those of other species. In this experiment, we used specific primers for the detection and identification of specific bacteriocin genes. For PCR amplification of the specific gene, specific primers were designed based on gene sequences available in the GenBank database.

\section{Amplification of bacteriocin encoding genes}

By performing the polymerase chain reaction, bacteriocin encoding genes of the chosen isolates were identified using different specific primer pairs, the primers for sakacin $P$, and bacterial genomic DNA. After the PCR, amplified products were analyzed by electrophoresis on $1 \%$ agarose gel (1X TAE buffer pH 8.3) 
using a $100 \mathrm{~kb}$ DNA ladder (Enzynomics) as a molecular weight standard weight. Electrophoresis was done at $80 \mathrm{~V}$ for $60 \mathrm{~min}$.

\section{Analysis of bacteriocin gene sequence}

The products of PCR were sent for sequencing to $1^{\text {st }}$ Base laboratory, Malaysia. Nucleotide sequencing of the PCR amplicon was compared with the GenBank database. Sequences were blasted against the NCBI GenBank database. Sequence alignment was performed. The gene sequences related to bacteriocin production were deposited in the NCBI, GenBank.

\section{Results}

Isolation of lactic acid bacteria

Fourteen bacterial strains were isolated, eight strains of Lactobacillus were isolated from four samples of minced meat (P1, P2, P3, P4, P5, P6, GCU-W-MS1, GCU-W-MS2), and six strains of Lactobacillus isolated from different sources of pickles (H1, GCU-W-PS1, H3, N1, GCU-W-PS2, N3) (Table 1).

Table 1. Isolated Lactobacilli strains from poultry meat and pickle sample

\begin{tabular}{|c|c|}
\hline Nature of sample & Isolated strains \\
\hline Minced poultry meat (Sant nagar) & $\mathrm{P} 1, \mathrm{P} 2$ \\
\hline Minced poultry meat (Sant nagar) & P3, P4 \\
\hline Minced poultry meat (Krishan nagar) & P5, GCU-W-MS1, \\
\hline Minced poultry meat (Krishan nagar) & P6, GCU-W_MS2 \\
\hline Pickle (mixed) Home made & H1, GCU-W-PS1 \\
\hline Pickle (mixed) Shan company & H3, \\
\hline Pickle (mixed) Shangrilla company & GCU-W-PS2 \\
\hline Pickle (mixed) Shezan company & GCU-W-PS2, N3 \\
\hline
\end{tabular}

\section{Morphological and biochemical characteristics}

Grams staining result showed that all the isolated strains were purple-stained and were gram-positive and were rod or cocci in shape (Table 2 and Figure 1). The results revealed that all isolated bacterial strains could not degrade hydrogen peroxide and were catalase-negative (Figure 2).

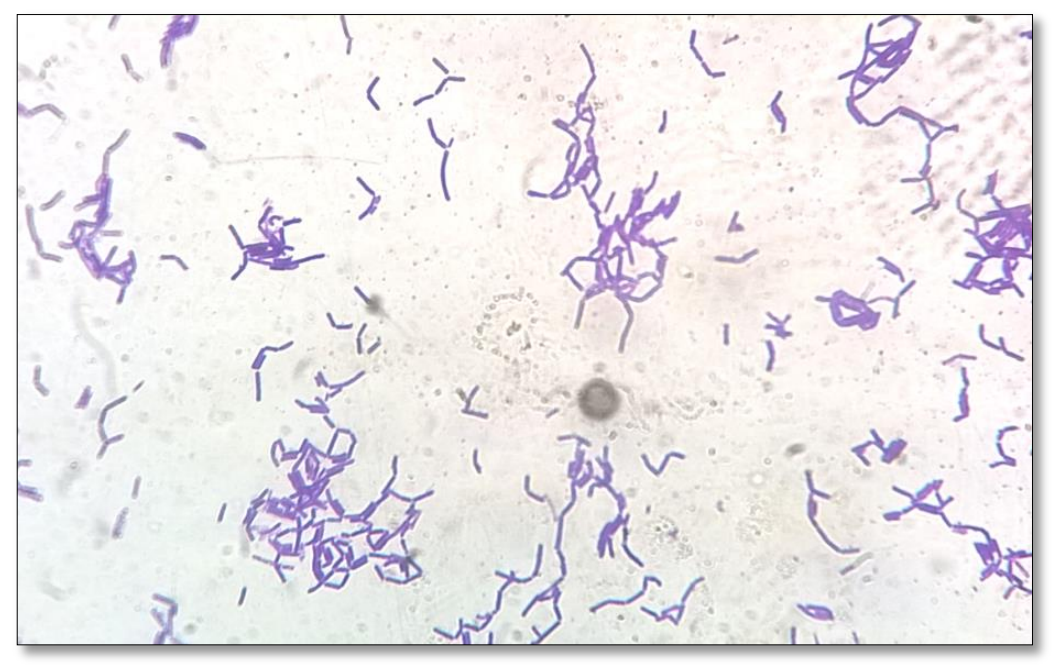

Figure 1. Gram staining test showing results of selected strains as a gram-positive 
Table 2. Morphological and biochemical characterization of bacterial isolates

\begin{tabular}{lccccc}
\hline Strains & $\begin{array}{c}\text { Colony } \\
\text { color }\end{array}$ & Colony size & $\begin{array}{c}\text { Colony } \\
\text { texture }\end{array}$ & $\begin{array}{c}\text { Gram } \\
\text { Staining }\end{array}$ & $\begin{array}{c}\text { Catalase } \\
\text { test }\end{array}$ \\
\hline P1 & White & medium & Wet & +ive & -ive \\
P2 & White & medium & Wet & +ive & -ive \\
P3 & Offwhite & small & Wet & +ive & -ive \\
P4 & Offwhite & medium & Wet & +ive & -ive \\
P5 & White & small & Wet & +ive & -ive \\
P6 & White & small & Wet & +ive & -ive \\
GCU-W-MS1 & Offwhite & medium & Dry & +ive & -ive \\
GCU-W-MS2 & Offwhite & small & Wet & +ive & -ive \\
H1 & White & small & Wet & +ive & -ive \\
GCU-W-PS1 & White & small & Wet & +ive & -ive \\
H3 & Offwhite & medium & Wet & +ive & -ive \\
N1 & Offwhite & medium & Wet & +ive & -ive \\
GCU-W-PS2 & Offwhite & medium & Wet & +ive & -ive \\
N3 & White & small & Wet & +ive & -ive \\
\hline
\end{tabular}

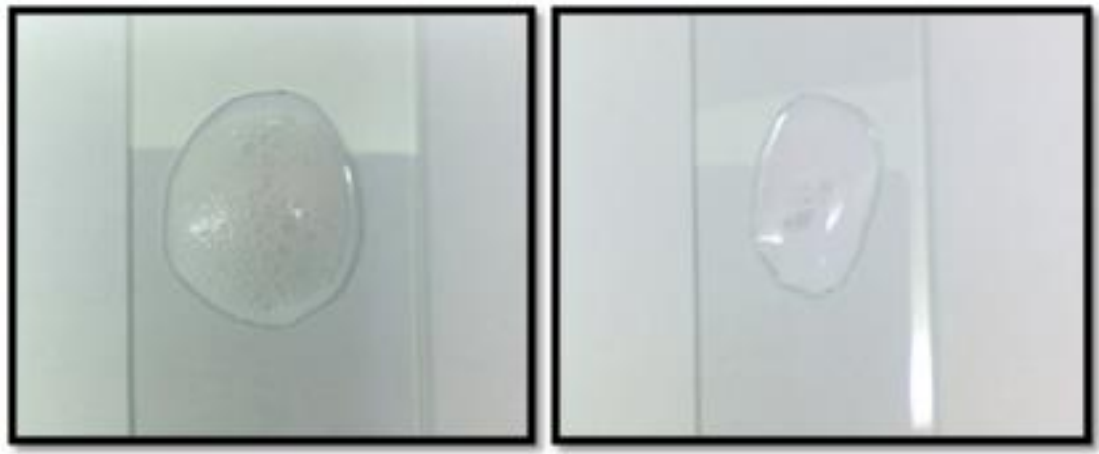

A) Catalase positive

B) Catalase negative

Figure 2. Catalase test showing negative results for selected strains

Agar well diffusion assay (inhibitory assay)

The agar well diffusion method revealed that GCU-W-MS1, MS2, GCU-W-PS1, and GCU-W-PS2 were found an active producer of bacteriocins (Table 3). GCU-W-MS1 showed maximum inhibition of Escherichia coli $(9 \mathrm{~mm})$. On the other hand, the least or even minimum inhibition of Salmonella enteritidis, $S$. aureus, $P$. aeruginosa, and $B$. thuringiensis was recorded.

Table 3. Inhibitory activity of bacteriocin of wild strains of Lactobacillus isolated from poultry meat and pickles against some pathogenic bacteria

Zone of inhibition $(\mathrm{mm})$

\begin{tabular}{|c|c|c|c|c|c|}
\hline \multirow[t]{2}{*}{ Sample no. } & $\begin{array}{c}\text { Salmonella } \\
\text { enteritidis }\end{array}$ & P. aeruginosa & Escherichia coli & S. aureus & B. thuringiensis \\
\hline & \multicolumn{5}{|c|}{$M \pm S . E$} \\
\hline GCU-W-PS2 & $5.1 \pm 00.10$ & $2.0 \pm 00.10$ & $3.0 \pm 00.10$ & $7.9 \pm 00.10$ & $2.0 \pm 00.20$ \\
\hline GCU-W-PS1 & $6.0 \pm 00.10$ & Resistant & $2.7 \pm 00.10$ & $7.5 \pm 00.20$ & $3.5 \pm 00.10$ \\
\hline GCU-W-MS1 & $8.2 \pm 00.20$ & $2.1 \pm 00.13$ & $8 \pm 00.15$ & $8.0 \pm 00.10$ & $2.7 \pm 00.13$ \\
\hline GCU-W-MS2 & $7.8 \pm 00.10$ & $3.3 \pm 00.10$ & $5.4 \pm 00.10$ & $9.2 \pm 00.14$ & $2.4 \pm 00.10$ \\
\hline
\end{tabular}

GCU-W-MS2 showed maximum inhibition of $S$. aureus and Salmonella enteritidis with $8 \mathrm{~mm}$ zone of inhibition, while Escherichia coli, P. aeruginosa, B. thuringiensis were resistant to L. johnsonii. GCU-W-PS1 showed maximum inhibition of $S$. aureus and Salmonella enteritidis with $7 \mathrm{~mm}$ zone of inhibition, while resistance to $P$. aeruginosa, Escherichia coli and $B$. thuringiensis showed less degree of inhibition with a zone of $3 \mathrm{~mm}$. GCU-W-PS2 showed a high degree of inhibition of $S$. aureus $(8 \mathrm{~mm})$. $P$. aeruginosa showed the least bacteriocin activity. 


\section{Mutagenesis in Lactobacillus spp.}

GCU-W-PS1, GCU-W-PS2, GCU-W-MS1 and GCU-W-MS2 strains were the species that showed maximum bacteriocin activities against pathogenic bacteria i.e., S. aureus, P. aeruginosa, B. thuringiensis, Escherichia coli, and Salmonella enteritis. So, the mutagenesis induction technique was being used on these strains to check either mutation makes them more reactive against a pathogen or not. Ethidium bromide is a teratogen chemical and can change the genetic makeup was being used for inducing mutation. Interestingly, it was observed morphologically and biochemically (bacteriocin assay) that mutation enhances the activity of L. curvatus, L. plantarum, and Lactobacillus sakei.

\section{Morphological characteristics of mutants' $\mathrm{v} / \mathrm{s}$ wild}

It can be seen that after mutation, the growth of different Lactobacillus strains has been increased at a high rate. The increased growth rate in mutants is shown in Figure 3, which is a comparison between wild and mutant Lactobacillus.
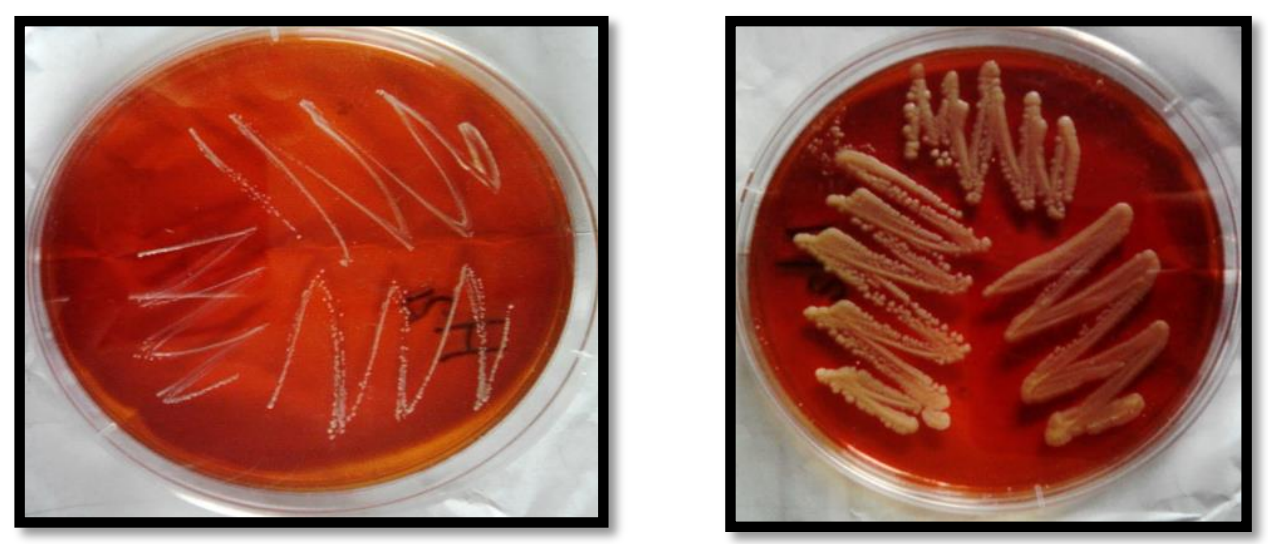

Figure 3. L. curvatus (wild and mutant)

\section{Bacteriocin assay}

Bacteriocin assay (agar well diffusion assay) was done again on mutant species of Lactobacillus i.e. L. curvatus, L. plantarum, Lactobacillus sakei, and Lactobacillus johnsonii (Figure 4). They showed more inhibition zone compared to wild species of Lactobacillus (Table 4).
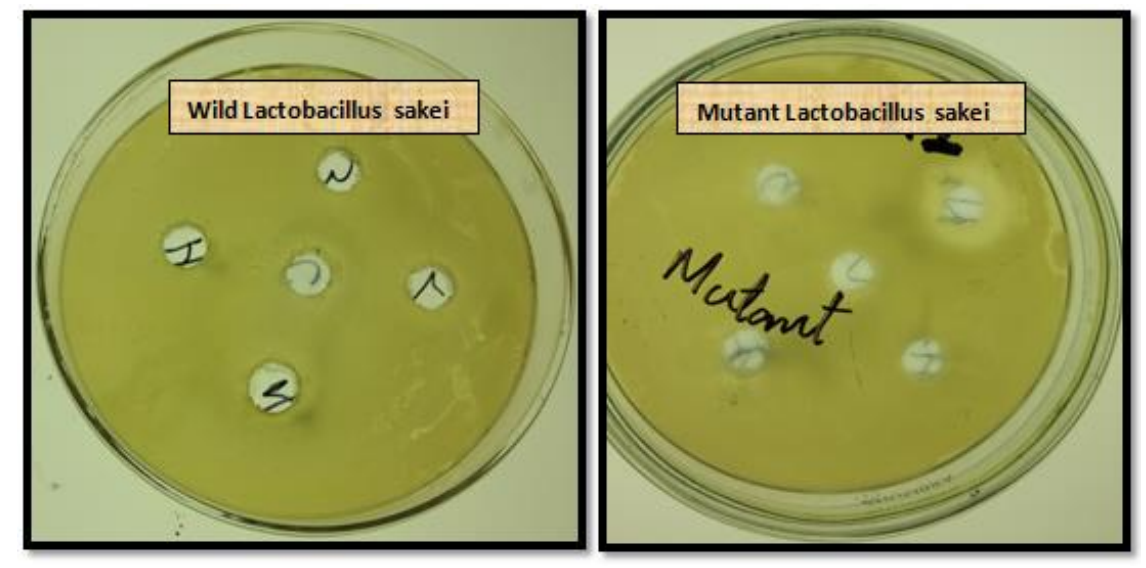

Figure 4. Comparison of antibacterial activity between wild and mutant species on pathogen S. aureus 
Table 4. Inhibitory activity of bacteriocin of mutant strains of Lactobacillus isolated from poultry meat and pickles against some pathogenic bacteria

Zone of inhibition $(\mathrm{mm})$

\begin{tabular}{lccccc} 
Sample no. & $\begin{array}{c}\text { Salmonella } \\
\text { enteritidis }\end{array}$ & P. aeruginosa & Escherichia coli & S. aureus & B. thuringiensis \\
\cline { 2 - 6 } & \multicolumn{5}{c}{ M \pm S.E } \\
\cline { 2 - 6 } GCU-W-PS2 & $5.5 \pm 00.16$ & $2.0 \pm 00.10$ & $4.0 \pm 00.10$ & $7.0 \pm 00.10$ & $2.0 \pm 00.20$ \\
GCU-W-PS1 & $9.0 \pm 00.18$ & $4.0 \pm 00.10$ & $5.0 \pm 00.10$ & $7.0 \pm 00.30$ & $3.0 \pm 00.10$ \\
GCU-W-MS1 & $7.0 \pm 00.25$ & $2.1 \pm 00.39$ & $5.0 \pm 00.15$ & $7.8 \pm 00.14$ & $3.0 \pm 00.13$ \\
GCU-W-MS2 & $8.0 \pm 00.10$ & Resistant & $6.0 \pm 00.10$ & $9.6 \pm 00.18$ & $2.1 \pm 00.10$ \\
\hline
\end{tabular}

\section{Characterization of bacteriocin}

Isolated strains CPS were being treated with pepsin which is a proteolytic enzyme. When pepsin was being added, it was seen that all isolated strains showed sensitivity against it (Table 5).

Table 5. Sensitivity of bacteriocin of bacterial isolates isolated from poultry meat and pickle towards pepsin

\begin{tabular}{llc}
\hline Serial no. & Isolated bacterial strains & $\begin{array}{c}\text { Sensitivity to Pepsin } \\
\text { (proteolytic enzyme) }\end{array}$ \\
\hline 1. & GCU-W-PS1 (L. plantarum) & Sensitive \\
2. & GCU-W-PS2 (Lactobacillus sakei) & Sensitive \\
3. & GCU-W-MS2 ( Lactobacillus johnsonii) & Sensitive \\
4. & GCU-W-MS1 ( L. curvatus) & Sensitive \\
5. & GCU-M-PS1 (L. plantarum) & Sensitive \\
6. & GCU-M-PS2 (Lactobacillus sakei) & Sensitive \\
7. & GCU-M-MS2 ( Lactobacillus johnsonii) & Sensitive \\
8. & GCU-M-MS1 ( L. curvatus) & Sensitive \\
\hline
\end{tabular}

Protein estimation by Bradford method

The standard curve of BSA was plotted (Figure 5 ) and protein concentration produced by Lactobacillus spp. was calculated.

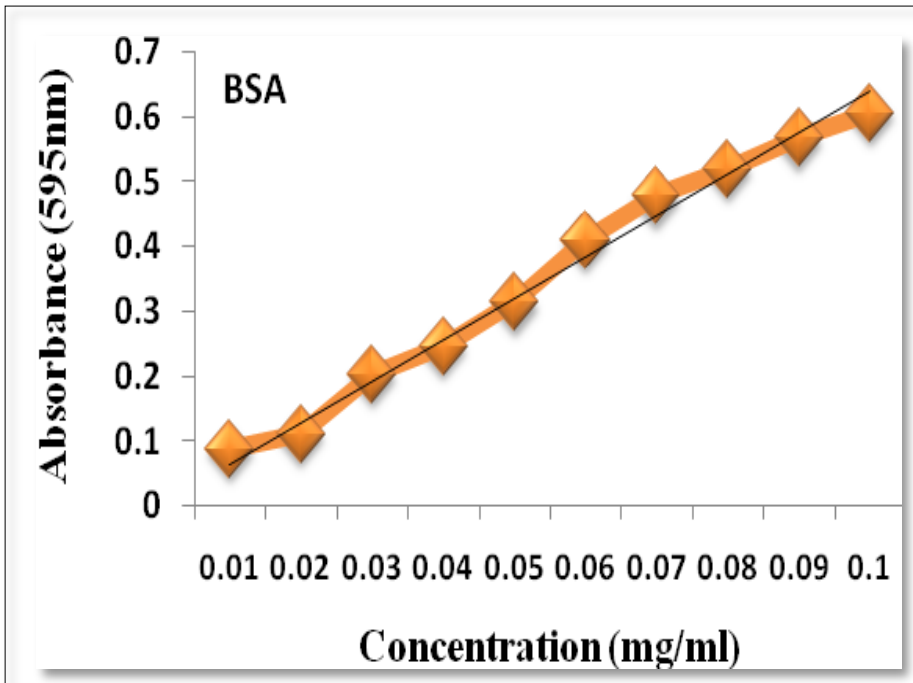

Figure 5. Standard curve of BSA

\section{Molecular characterizations}

Strains with the best inhibitory activity were selected for molecular characterization (Table 6). $1 \%$ gel was prepared and about $4 \mu \mathrm{I}$ DNA sample was loaded for gel electrophoresis sharp bands of genomic DNA of GCU-W-PS1, GCU-M-PS1, GCU-W-PS2, GCU-M-PS2, GCU-W-MS1 and GCU-M-MS1 were visualized (Figure 
6). Universal forward and reverse primers were used to amplify genomic DNA and $1 \%$ agarose gel was being used to check PCR product (Figure 7).

Table 6. Accession number given to identified strains

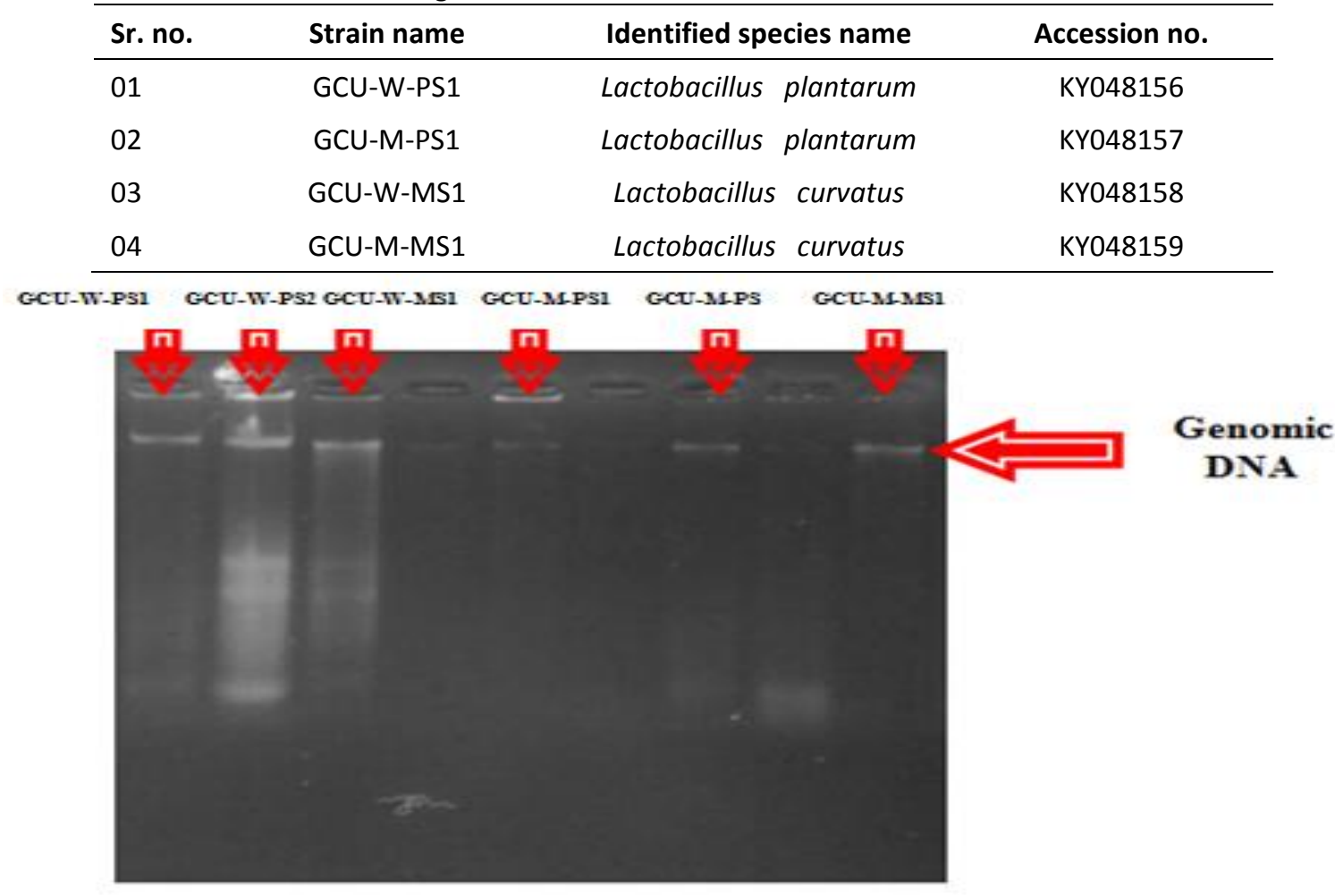

Figure 6. $1 \%$ agarose gel GCU-W-PS1, GCU-W-PS2, GCU-W-MS1, GCU-M-PS1, GCU-M-PS, GCU-M-MS1 indicates the genomic DNA isolated from poultry and pickle samples and their mutants

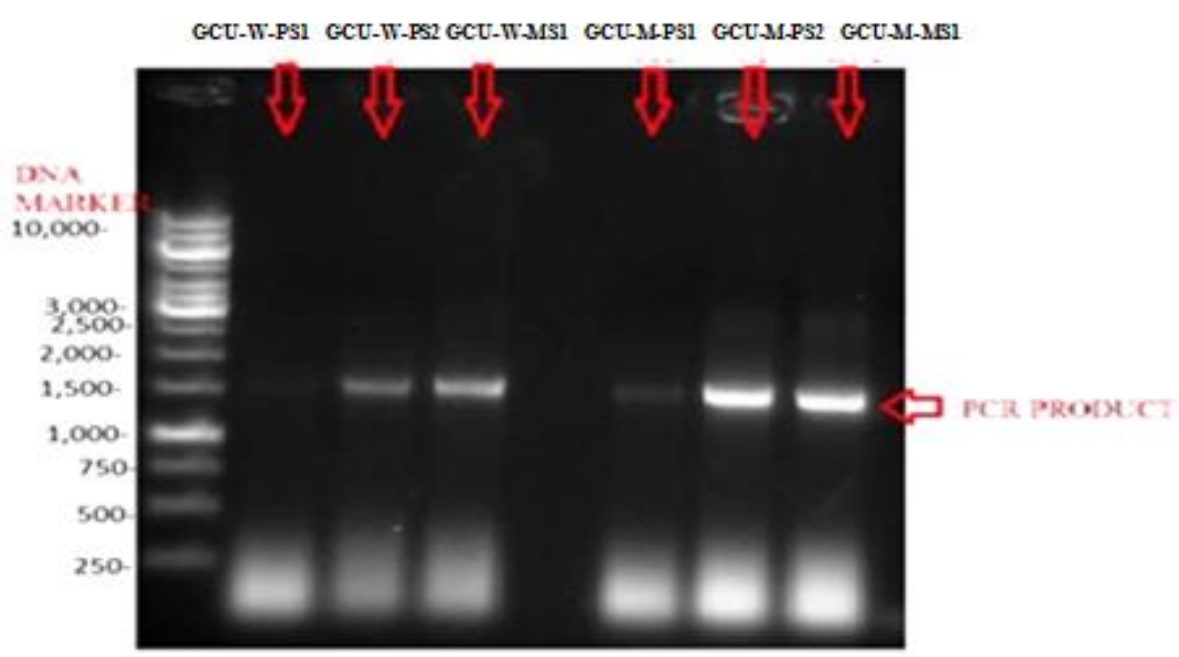

Figure 7. Agarose gel 1\% GCU-W-PS1, GCU-W-PS2, GCU-W-MS1, GCU-M-PS1, GCU-M-PS2, GCU-M-MS1 indicates the PCR products of genomic DNA of isolated wild Lactobacilli from poultry and pickle samples and their mutants.

\section{Sequencing and sequence analysis}

For the sequencing of PCR products, the samples were sent to $1^{\text {st }}$ Base Laboratory, Malaysia. It was found that GCU-W-PS1 (wild) and GCU-M-PS1 (mutant) have $97 \%$ and $99 \%$ resemblance with L. plantarum respectively. GCU-W-MS1 (wild) and GCU-M-MS1 (mutant) strains showed a resemblance $98 \%$ with $L$. curvatus (Table 6). 


\section{Characterization of bacteriocin encoding genes}

Using specific primers designed for curvacin, sakacin, and plantaricin genes, strains that showed maximum antibacterial activity were amplified. PCR results had shown GCU-W-MS1 (wild) and GCU-M-MS1 (mutant) (L. curvatus) strain amplified for curvacin gene and showed $100 \%$ homology (Figure 8).

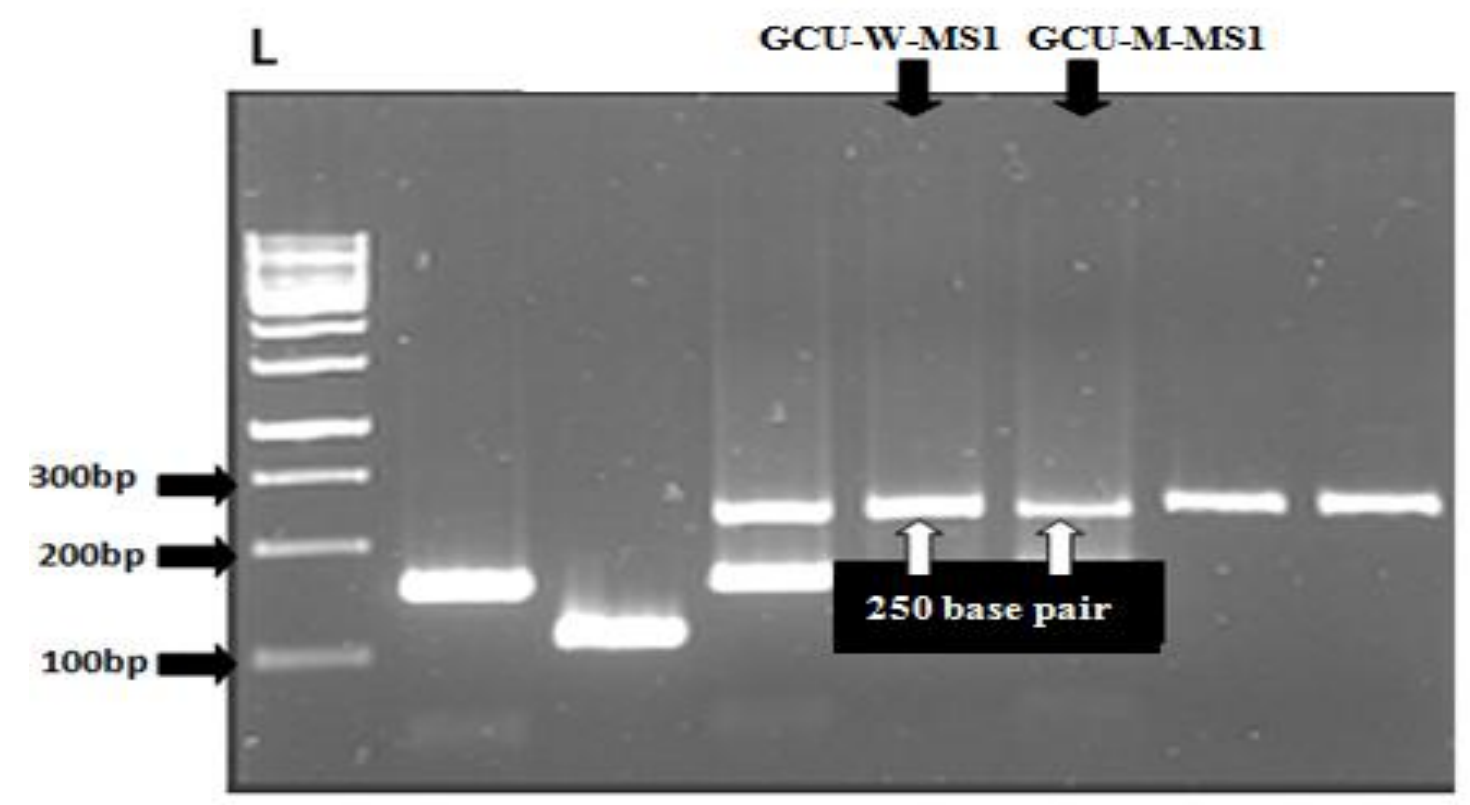

Figure 8. Agarose gel electrophoresis of PCR fragments generated with curvacin A specific primer from DNA of selected GCU-W-MS1 and GCU-W-MS1m strain (L. curvatus)

\section{Discussion}

Food safety is becoming a big challenge now a day. In the food industry, the use of chemical preservatives has a positive effect; however, they have some negative impacts on the health of human beings [13]. Modern society is more concerned about food safety as chemicals and artificial additives are eliciting poisonous concerns. So era demands to use natural sources for bio-safety and health. Bacteriocins are the natural compounds found in probiotics, especially LAB, i.e., mostly Lactobacillus species [14]. These compounds can kill pathogens found in food, preserve it, and avoid the degradation of food. And they were generally recognized as safe (GRAS). Usually, Lactobacillus bacteria can be isolated from yogurt, pickles, and meat. Bacteriocin produced by Lactobacillus promises safe to use as a food preservative found in vegetables, cheese, dairy products, and meat, as they inhibit pathogenic contamination during the processing [15]. They show high antimicrobial activity against disease-causing bacteria [16]. The inhibition zone can be counted as positive if the zone is $2 \mathrm{~mm}$ or greater than $2 \mathrm{~mm}$. And the present study shows that the strains i.e. GCU-W-PS1, GCU-W-PS2, GCU-W-MS1, and GCU-W-MS2, exhibit a greater inhibition zone of more than $2 \mathrm{~mm}$. The highest degree of inhibition that was measured is more than $9 \mathrm{~mm}$. GCU-W-MS2 was the strain isolated from meat that had shown a high degree of inhibition on the culture plate of $S$. aureus $9.2 \mathrm{~mm}$. However, a strain isolated from pickles named GCU-W-PS1 showed resistance for $P$. aeruginosa. [17] used well diffusion method to ensure the antibacterial activity of lactic acid bacteria of raw milk of cattle against S. aureus, Bacillus mycoides, Proteus valgaris, and Klebsiella pneumonia, these pathogens were found to be sensitive for bacteriocin produced by Lactobacillus species [18]. As these strains showed more bacteriocin active results, they were selected for the induction of mutagenesis to check whether a mutation will increase the efficiency against a pathogen. The results have shown that mutagenesis increases the efficiency in some bacteria i.e., GCU-W-PS1 which had no bacterial activity and exhibited no 
inhibition zone. However, present work showed that after mutation, the pathogenicity of GCU-M-PS1 increased, showing an inhibition zone of $4 \mathrm{~mm}$ against $P$. aeruginosa. By site-directed mutagenesis in bacterial structural genes and with the help of genomics and proteomics, this could be made possible to construct a new family with peptides to increase the antibacterial activity [19]. Biochemical testing (i.e., sensitivity to proteolytic enzymes and protein estimation by Bradford method) and molecular characterization have been proved that mutant strains of Lactobacillus have more virulence against pathogens. In [20], a large number of Gram-positive bacteria, including food-borne pathogen Listeria monocytogenes, Bacillus cereus, and S. aureus, were inhibited by bacteriocin produced by L. plantarum. The analysis of LAB bacteria from poultry meat and pickle in this study indicated several bacterial genera with the ability of bacteriocin production [21]. In conclusion, the P11 strain (L. curvatus) has bacteriocin encoding gene exhibited inhibitory activity against pathogenic bacteria. Time-saving methods must be used for characterization. One of them is PCR which is used for rapid identification. Through the PCR bacteriocin encoding, genes were detected. The strains P7, P11 were amplified with already reported primers. Generally, one species of bacteria may produce more than one type of bacteriocin and one bacteriocin may not produce by single species of bacteria. Two subspecies of $L$. plantarum isolated from different sources, such as fermented sausages and cucumber fermentation were shown to have the same plantaricin encoding gene PInA [22,23]. Curvacin A encoding gene was identified in both the L. curvatus and Lactobacillus sakeii [24]. In the present study, the GCU-W-PS1 (L. curvatus) strain was amplified with curvacin A gene.

\section{Conclusion}

The ability to produce bacteriocins provides the antibacterial potential to lactic acid bacteria against various common pathogens like Pseudomonas aeruginosa, Staphylococcus aureus, Bacillus thuringiensis, Escherichia coli, and Salmonella enteritis. They show antibacterial activity against both their wild and mutant strains. Bacteriocins are safe to use with a minimum negative impact on human health because they are natural products and should be considered safe for food and preservation in the food and dairy industries.

Conflict of interest: The authors declare that they have no known competing financial interests or personal relationships that could have appeared to influence the work reported in this paper.

\section{References}

[1] E. Pasolli, F. De Filippis, I.E. Mauriello, F. Cumbo, A.M. Walsh, J. Leech, P.D. Cotter, N. Segata, D. Ercolini. Large-scale genome-wide analysis links lactic acid bacteria from food with the gut microbiome. Nat. Commun. 11 (2020) 2610. https:/doi.org/10.1038/s41467-020-16438-8.

[2] D. Dordević, S. Jančíková, M. Vítězová, I. Kushkevych. Hydrogen sulfide toxicity in the gut environment: Meta-analysis of sulfate-reducing and lactic acid bacteria in inflammatory processes. $J$. Adv. Res. 27 (2021) 55-69. https://doi.org/10.1016/i.jare.2020.03.003.

[3] W. Churklam, S. Chaturongaku, B, Ngamwongsatit, B. Aunpad. The mechanisms of action of carvacrol and its synergism with nisin against Listeria monocytogenes on sliced bologna sausage. Food Control 108 (2020) 106864. https://doi.org/10.1016/i.foodcont.2019.106864.

[4] A.B. Snyder, R.W. Worobo. Chemical and genetic characterization of bacteriocins: antimicrobial peptides for food safety. J. Sci. Food Agric. 94 (2014) 28-44. https://doi.org/10.1002/isfa.6293.

[5] D. Drider, G. Fimland, Y. Héchard, L.M. McMullen, H. Prévost. The continuing story of class Ila bacteriocins. Microbiol. Mol. Biol. Rev. 70 (2006) 564-582. https://doi.org/10.1128/MMBR.00016-05. 
[6] D. Gawel, M. Maliszewska-Tkaczyk, P. Jonczyk, R.M. Schaaper, I.J. Fijalkowska. Lack of strand bias in UV-induced mutagenesis in Escherichia coli. J. Bacteriol. 184 (2002) 4449-4454. https://doi.org/10.1128/JB.184.16.4449-4454.2002.

[7] F. Kamal, N. Samadi, N. Moazami, M. R. Fazeli. Mutagenesis of Leuconostoc Mesenteroides and selection of Dextransucrase hyperproducing strains. DARU J. Pharm. Sci. 9 (2001) 18-23. https://www.sid.ir/en/Journal/ViewPaper.aspx?ID=34248.

[8] Y. Sobrun, A. Bhaw-Luximon, D. Jhurry, D. Puchooa. Isolation of lactic acid bacteria from sugar cane juice and production of lactic acid from selected improved strains. Adv. Biosci. Biotech. 3 (2012). https://doi.org/10.4236/abb.2012.34057.

[9] Ünlü, B. Nielsen, C. Ionita. Production of Antilisterial Bacteriocins from Lactic Acid Bacteria in DairyBased Media: A Comparative Study. Probiotics Antimicrob. Proteins 7 (2015) 259-274. https://doi.org/10.1007/s12602-015-9200-z.

[10] D. Lynch, P.M. O'Connor, P.D. Cotter, C. Hill, D. Field, M. Begley. Identification and characterisation of capidermicin, a novel bacteriocin produced by Staphylococcus capitis. PLoS One 14 (2019) e0223541. https://doi.org/10.1371/journal.pone.0223541.

[11] H.F. Tai, H.L. Foo, R. Abdul Rahim, T.C. Loh, M.P. Abdullah, K. Yoshinobu. Molecular characterisation of new organisation of plnEF and plw loci of bacteriocin genes harbour concomitantly in Lactobacillus plantarum I-UL4. Microb. Cell Fact. 14 (2015) 89. https://doi.org/10.1186/s12934-015-0280-y.

[12] M.M. Bradford. A rapid and sensitive method for the quantitation of microgram quantities of protein utilizing the principle of protein-dye binding. Anal. Biochem. 72 (1976) 248-254. https://doi.org/10.1006/abio.1976.9999.

[13] A. Endo, S. Maeno, Y. Tanizawa, W. Kneifel, M. Arita, L. Dicks, S. Salminen. Fructophilic Lactic Acid Bacteria, a Unique Group of Fructose-Fermenting Microbes. Appl. Environ. Microbiol. 84 (2018) e01290-18. https://doi.org/10.1128/AEM.01290-18.

[14] R. Hatti-Kaul, L. Chen, T. Dishisha, H.E. Enshasy. Lactic acid bacteria: from starter cultures to producers of chemicals. FEMS Microbiol. Lett. 365 (2018). https://doi.org/10.1093/femsle/fny213.

[15] L.H. Deegan, P.D. Cotter, H. Colin. Bacteriocins: biological tools for bio-preservation and shelf-life extension. International Dairy Journal 16 (2006) 1058-1071. https://doi.org/10.1016/i.idairyj.2005.10.026.

[16] S.F. Henriques, D.B. Dhakan, L. Serra, A.P. Francisco, Z. Carvalho-Santos, C. Baltazar, A.P. Elias, M. Anjos, T. Zhang, O.D.K. Maddocks, C. Ribeiro. Metabolic cross-feeding in imbalanced diets allows gut microbes to improve reproduction and alter host behaviour. Nat. Commun. 11 (2020) 4236. https://doi.org/10.1038/s41467-020-18049-9.

[17] A. Mohankumar, N. Murugalatha. Characterization and antibacterial activity of bacteriocin producing Lactobacillus isolated from raw cattle milk sample. International Journal of Biology 3 (2011) 128. https://doi.org/10.5539/ijb.v3n3p128.

[18] L.G. Ruiz Rodríguez, F. Mohamed, J. Bleckwedel, R. Medina, L. De Vuyst, E.M. Hebert, F. Mozzi. Diversity and Functional Properties of Lactic Acid Bacteria Isolated From Wild Fruits and Flowers Present in Northern Argentina. Front. Microbiol. 10 (2019) 1091. https://doi.org/10.3389/fmicb.2019.01091.

[19] W.S. Kim, R. J. Hall, and N. W. Dunn. Improving nisin production by increasing nisin immunity/resistance genes in the producer organism Lactococcus lactis." Applied microbiology and biotechnology 50 (1998) 429-433. https://doi.org/10.1007/s002530051316.

[20] I. Askoul, S.A. Gorrah, L. Al-Amir. Isolation and Characterization of Bacteriocin Producing Lactic Acid Bacteria from some Syrian fermented foods. International Journal of ChemTech Research 6 (2014), 2507-2520. https://sphinxsai.com/2014/vol6pt4/4/(2507-2520)Jul-Aug14.pdf.

[21] A. Sharma, S. Lee, Y.S. Park. Molecular typing tools for identifying and characterizing lactic acid bacteria: a review. Food Sci. Biotechnol. 29 (2020) 1301-1318. https://doi.org/10.1007/s10068-020$\underline{00802-x}$. 
[22] R. Shylaja, D. Selvakumar, J.H. Jagannath. Isolation and identification of lactic acid bacteria from raw and fermented products and their antibacterial activity. Recent Research in Science and Technology 2 (2010) 42-46.

[23] S. Saltaji, O. Rué, V. Sopena, S. Sablé, F. Tambadou, S. Didelot, R. Chevrot. Lactococcus lactis Diversity Revealed by Targeted Amplicon Sequencing of purR Gene, Metabolic Comparisons and Antimicrobial Properties in an Undefined Mixed Starter Culture Used for Soft-Cheese Manufacture. Foods 9 (2020) E622. https://doi.org/10.3390/foods9050622.

[24] S.D. Todorov, C. Rachman, A. Fourrier, L.M. Dicks, C.A. van Reenen, H. Prévost, X. Dousset. Characterization of a bacteriocin produced by Lactobacillus sakei R1333 isolated from smoked salmon. Anaerobe 17 (2011) 23-31. https://doi.org/10.1016/j.anaerobe.2010.01.004.

C2021 by the authors; licensee IAPC, Zagreb, Croatia. This article is an open-access article distributed under the terms and conditions of the Creative Commons Attribution license (http://creativecommons.org/licenses/by/3.0/) (cc) EY 